\title{
The Effect of Resection Methods on Outcomes in Colorectal Cancers: Does Conversion Matter?
}

\section{Kolorektal Kanserlerde Rezeksiyon Metodunun Sonuçlara Etkisi: Konversiyon Önemli mi?}

\author{
Umut Eren Erdoğdu, Hacı Murat Çaycı \\ University of Health Sciences, Bursa Yüksek İhtisas Training and Research Hospital, Department of General Surgery, Bursa, Turkey
}

\begin{abstract}
|IIIIIII| ABSTRACT
Aim: In this study, we aim to evaluate the short and long-term outcomes of patients undergoing conversion from laparoscopy to open surgery compared to other methods (laparoscopy and open surgery).

Method: The data of 98 patients, who underwent elective surgery due to colorectal cancer in a single center, were retrospectively analyzed. Based on the resection method, patients were divided into three groups: laparoscopy, open and conversion. The demographic characteristics, comorbidity, colonic localization, colonic transit properties, preoperative metastasis, resection type, morbidity and mortality, lymph node metastasis, stage, followup duration, recurrence and overall survival data were recorded and compared.

Results: The morbidity incidence was highest in the conversion group (63.6\%) ( $\mathrm{p}=0.012)$. There was no statistical difference in the morbidity subgroup analyses between laparoscopy and open surgery groups $(\mathrm{p}=0.752)$, whereas the incidence of morbidity in the conversion group was statistically higher than both the laparoscopy and open surgery groups ( $\mathrm{p}=0.009$ and $\mathrm{p}=0.025$, respectively). During follow-up, recurrence was observed in two patients $(4.50 \%)$ in the laparoscopy group and in two patients (4.50\%) in the open surgery group. There was no difference one, two, and three-year survival rates among the three groups.

Conclusion: In colorectal cancers, morbidity is observed more frequently in patients in the early stage of the disease who undergo conversion; however, with regard to short and long-term oncological outcomes, there is no difference in resection methods.
\end{abstract}

Keywords: Colorectal cancer, laparoscopy, open surgery, conversion

\section{IIIIIIII| ÖZ}

Amaç: Çalışmamızda kolorektal kanserlerde laparoskopiden açığa konversiyon ve diğer yöntemlerin (laparoskopi ve açık cerrahi) kısa ve uzun dönemde sonuçlarının değerlendirilmesi amaçlanmıştır.

Yöntem: Mayıs 2013 ile Aralık 2016 tarihleri arasında kolorektal kanser nedeniyle aynı merkezde elektif opere edilen 98 hastanın medikal verileri retrospektif olarak değerlendirildi. Hastalar rezeksiyon metoduna göre laparoskopi ( $\mathrm{n}=44)$, açık ( $\mathrm{n}=43$ ) ve konversiyon ( $\mathrm{n=11}$ ) olarak üç gruba ayrıldı. Gruplarda hastaların demografik özellikler, komorbidite varlığı, tümörün kolonik yerleşimi, kolonoskopide geçiş özellikleri, preoperatif metastaz, rezeksiyon tipi, morbidite ve mortalite, lenf bezi metastazı ve hastalık evresi, takip süreleri, nüks ve genel sağkalım verileri kaydedildi ve karşılaştırıldı. Bulgular: Kolorektal kanser nedeniyle 44 (44,89\%) laparoskopik, 43 (43,87\%) open ve 11 (11,2\%) konversiyon kolon rezeksiyonu uygulandı. Demografik özellikler, komorbidite, tümör lokalizasyonu, rezeksiyon tipi, operasyon süresi, mortalite, stage ve sağkalım açısından gruplar arasında farklılık saptanmadı. Morbidite en sık konversiyon grubunda (63,6\%) olduğu görüldü $(\mathrm{p}=0,012)$. Morbidite alt grup analizleri yapıldı̆̆ında laparoskopi ve open cerrahi grupları arasında istatistiksel farklılık bulunmazken ( $\mathrm{p}=0,752)$; konversiyon grubunda morbidite görülme oranı hem laparoskopi grubundan hem de open cerrahi grubundan istatistiksel olarak daha yüksek bulundu (sırasıyla p=0,009 ve p=0,025). Takip döneminde nüks laparoskopi grubunda 2 (4,50\%) hastada, open cerrahi grubunda 2 (4,50\%) hastada görüldü. Konversiyon grubunda hastalık nüksü görülmedi. Bir, iki ve üç yıllık sağkalım açısından gruplar arasında farklılık görülmedi.

Sonuç: Kolorektal kanserlerde erken dönemde konversiyon uygulanan hastalarda morbidite daha sık görülmekte; ancak kısa ve uzun dönem onkolojik sonuçlarda rezeksiyon metodları arasında farklılık bulunmamaktadır.

Anahtar Kelimeler: Kolorektal kanser, laparoskopi, açık cerrahi, konversiyonç

Address for Correspondence/Yazışma Adresi: Umut Eren Erdoğdu MD

University of Health Sciences, Bursa Yüksek İhtisas Training and Research Hospital, Department of General Surgery, Bursa, Turkey

Phone: +90 5325434838 E-mail: umuterdogdu@gmail.com ORCID ID: orcid.org/0000-0001-6700-1858

Received/Geliş Tarihi: 18.10.2017 Accepted/Kabul Tarihi: 29.11.2017

${ }^{\circ}$ Copyright 2017 by Turkish Society of Colon and Rectal Surgery

Turkish Journal of Colorectal Disease published by Galenos Publishing House. 


\section{Introduction}

Laparoscopic surgical interventions have been widely used in benign and malignant colorectal diseases since $1990 .{ }^{1}$ There are many advantages to laparoscopic resection compared to conventional open surgery; including less postoperative pain, uncompromised pulmonary functions, no conspicuous incision, quicker mobilization and recovery time, and a decrease in morbidity and hospitalization time. ${ }^{2}$ Furthermore, as therapeutic properties are not negatively affected after laparoscopic interventions, postoperative adjuvant treatments can be started earlier. ${ }^{3}$ Despite the ongoing discussion as to whether laparoscopic resections can ensure better results than open surgery, they are performed with increasing frequency. ${ }^{4,5}$ However, although their short term and oncological outcomes are similar, the percentage of laparoscopic resections performed is still lower than open surgery. ${ }^{6}$

In the catalogue of minimally invasive surgical interventions, the term "conversion" has now been added to the classic resection methods. Conversion is defined as termination of the laparoscopic procedure for cause and switching to open surgery via mid-line incision. The conversion rate for colorectal cancers usually varies between $1.9 \%$ and $40.9 \%$. Conversion from laparoscopy to open surgery is not only considered as a complication, but also there is limited data to show whether identical outcomes to full laparoscopic resection can be obtained. While studies usually focus on outcomes for laparoscopy and open surgery, the results of conversion as a separate group are either not evaluated or are added into the open surgery outcomes. The postoperative outcomes of patients undergoing conversion are also not clear: when conversion cases are compared with laparoscopy and open surgery cases, exact data on operation time, hospitalization duration, morbidity, mortality and oncologic outcomes is not yet available..$^{8,910}$ Consequently, there is ongoing debate about whether laparoscopic interventions should be recommended to all patients with colorectal pathology, and how to identify patients at risk of conversion.

In this retrospective study, we aimed to compare the short and long-term outcomes of cases converted from laparoscopy to open surgery with other methods (laparoscopy and open surgery) over a three-year follow-up period.

\section{Materials and Methods}

\section{Study Population}

Medical data from a total of 98 patients undergoing elective resection for colorectal cancer, in a single center between May 2013 and December 2016, were retrospectively evaluated. All operations were carried out in a single center by a single surgical team. A total of 21 patients were excluded from the study for several reasons: their surgery was for benign causes (diverticulitis, inflammatory bowel disease); they underwent emergency surgery or were diagnosed with colorectal cancer during the surgery; palliative interventions (stent, etc.) were applied to the area of malignancy; the surgery was due to recurrent colorectal cancer. A total of 98 patients who complied with our criteria were included in the study. Detailed information about the operation was provided to the participating patients and a written informed consent was obtained from each one. The study was conducted in accordance with the principles of the Declaration of Helsinki.

Patients were divided into three groups based on the resection method: laparoscopy $(n=44)$, open $(n=43)$, and conversion $(n=11)$. Demographic characteristics of the patients; comorbidity; colonic localization of the tumor; colonic transit properties during colonoscopy; preoperative metastasis; resection type; morbidity and mortality; lymph node metastasis and stage of the disease; follow-up duration; recurrence and overall survival data were recorded and compared.

The presence of a carcinoma in all patients with colorectal cancer was confirmed histologically with a preoperative colonoscopy. For preoperative staging in cases with colon cancer, imaging was performed using computed tomography and magnetic resonance imaging (MRI), if necessary. In cases of rectal cancer, a routine pelvic MRI was taken.

\section{The Surgical Technique}

The resection types used were right or left hemicolectomy, anterior or low anterior resection (LAR) or abdominoperineal resection. Laparoscopic surgical intervention could not be performed in patients with invasion of surrounding organs, with a history of intraabdominal operation, or in cases of technical problems. Hybrid laparoscopy was avoided and anastomoses were applied intracorporeally. In all laparoscopy, open, and conversion methods, the tumor was resected en bloc, along with any surrounding areas invaded by the tumor, and local lymph nodes, following the no-touch technique. ${ }^{11}$ Ostomies were routinely created if patients had a history of radiotherapy in the rectal region or anastomosis in the lower rectum.

A liquid diet and oral enteral supplement was administered preoperatively to all patients undergoing resection. The night prior to surgery, all patients were administered with a low molecular weight heparin derivative (Clexane 8000 anti-Xa IU/0,8, Aventis), and prophylaxis for deep vein thrombosis. There was no particular bowel preparation in the preoperative period. Following post-operative gas emission, a liquid diet was started and patients who could 
tolerate oral intake and developed no signs of morbidity were discharged. In terms of preoperative evaluation and postoperative care, there was no difference in approach for patients in the various groups. In the postoperative period, patients were called for checkup three times in the first year and biannually in the second and third years for full evaluation.

\section{Statistical Analysis}

Statistical analysis was performed using SPSS version 22 (IBM Corp. released 2012), IBM SPSS Statistics for Windows, Version 21.0. (IBM Corp., Armonk, New York, USA). Descriptive data was expressed as mean \pm standard deviation (minimum:maximum) or median (minimum:maximum). The Shapiro-Wilk test was used to assess whether the variables followed normal distribution or not. According to normality test results, either one way analysis of variance or Kruskal-Wallis test were used for comparing the operation types. Categorical variables were compared using the FisherFreeman-Halton, Fisher's exact, and chi-square tests. The log-rank test was used to determine the difference in the Kaplan-Meier curves for disease-free survival time. The mean survival time was reported. A p value of $<0.05$ was considered statistically significant.

\section{Results}

In treating our patients for colorectal cancer, we carried out laparoscopic surgery on 44 (44.89\%) patients, open surgery in $43(43.87 \%)$ patients, and laparoscopic conversion resection in 11 (11.2\%). The demographic characteristics, presence of comorbidity, colonic localization of the cancer, colonic transit features noticed during colonoscopy, and the presence of preoperative metastasis for the three groups are presented in Table 1. Demographically, age, gender and body mass index (BMI) values were similar among the three groups and no statistical differences were found ( $\mathrm{p}=0.467$, $\mathrm{p}=0.341, \mathrm{p}=0.542$, respectively). Although comorbidity was more frequently observed in the conversion group, no statistically significant differences were detected among the three groups $(\mathrm{p}=0.182)$.

In all groups, the tumor was most frequently localized in the left colon (Table 1). In the laparoscopy and open surgery groups, the second most frequent localization was the rectum; and in the conversion group, it was the right colon; however, no statistical difference was observed among the groups in terms of tumor localization ( $\mathrm{p}=0.362$ ). In the preoperative period, liver metastases were observed in the laparoscopy and open surgery groups, but not in the conversion group $(\mathrm{p}=0.361)$. In the preoperative period,

Table 1. Demographic and histopathologic features

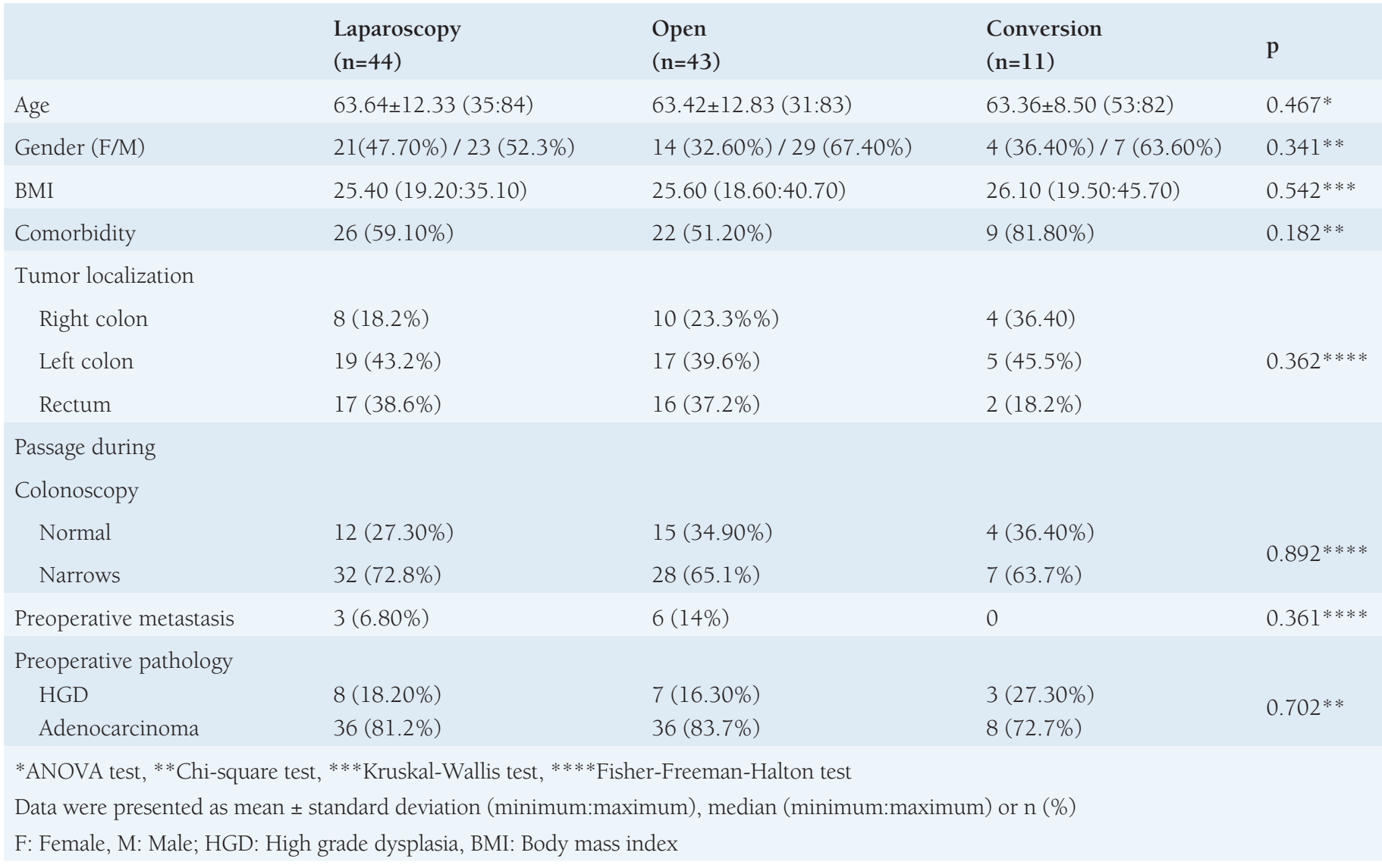


patients with metastases were reviewed by the oncology council and underwent resection as their first-line therapy. The histopathology diagnosis in the preoperative period was high grade dysplasia for $18.6 \%$ of the patients and adenocarcinoma for $81.4 \%$ of the patients $(\mathrm{p}=0.702)$. Neoadjuvant chemotherapy and radiotherapy was given to 17 patients (17.3\%) with rectal cancer.

The resection type and method, duration of operation, postoperative morbidity and mortality in the three groups are presented in Table 2. LAR and right hemicolectomy were the most frequently performed resection types in all three groups. Subtotal colectomy was performed only in the open surgery group. Laparoscopy was performed in nine patients (52.9\%), open surgery in six patients (35.2\%), and conversion from laparoscopy was required in two patients $(11.7 \%)$ receiving neoadjuvant chemotherapy and radiotherapy. The operation duration was similar in all three groups ( $\mathrm{p}=0.298$ ). Ileostomy was performed in four patients (9.09\%) in the laparoscopy group, 14 patients (32.5\%) in the open surgery group, and in three patients (27.2\%) in the conversion group.

The reasons for conversion surgery were: local invasion in 5 patients (45.4\%); severe adhesions in 2 patients (18.1\%); severe intestinal dilatation in 2 patients (18.1\%); narrow pelvis in 1 patient (9\%); and ureteral injury in 1 patient (9\%).

The most frequent cause of morbidity in all three groups was wound site infection and postoperative morbidity was most frequently observed in the conversion group (63.6\%) ( $\mathrm{p}=0.012$; Table 2 ). When morbidity subgroup analyses were performed, no statistical difference was found between the laparoscopy and open surgery groups $(\mathrm{p}=0.752)$, whereas the incidence of morbidity in the conversion group was statistically higher than that of both the laparoscopy group and the open surgery group $(\mathrm{p}=0.009$ and $\mathrm{p}=0.025$, respectively). Anastomotic leakage was observed in one patient $(1.02 \%)$ in the laparoscopy group, and in one patient $(1.02 \%)$ in the open surgery group. Two deaths occurred in the open surgery group: one due to hepatic failure (1.02\%) and one due to myocardial infarction (1.02\%); and one death in the conversion group ensued because of necrotizing fasciitis (1.02\%). No mortalities were recorded in the laparoscopy group. There was no statistically significant difference between the subgroups in terms of mortality ( $\mathrm{p}=0.098)$.

Following resection, pathology samples were examined, and stage and presence of metastases in the lymph node were evaluated for the three groups (Table 3). Similar numbers of lymph nodes were removed in all three groups $(\mathrm{p}=0.178)$ and no difference in terms of tumor size was detected among the three groups $(\mathrm{p}=0.626)$. When patient stages were evaluated, the most frequently observed stage in all three groups was stage 3 ( $45.5 \%, 37.2 \%$ and $63.6 \%$, respectively). Statistical analysis for the stages revealed no significant difference among the three groups $(\mathrm{p}=0.701)$.

Recurrence rate in the follow-up period, mean followup duration and overall survival values were presented in Table 3. In the follow-up period, recurrence was seen in two patients (4.50\%) in the laparoscopy group, and in two patients $(4.50 \%)$ in the open surgery group. No recurrence was observed in the conversion group. In terms of recurrence, no statistically significant differences were observed among the groups $(\mathrm{p}=1.00)$. The groups also had similar one, two, and three-year survival rates (Figure 1).

Table 2. Resection method, morbidity and mortality

\begin{tabular}{|c|c|c|c|c|}
\hline & $\begin{array}{l}\text { Laparoscopy } \\
(n=44)\end{array}$ & $\begin{array}{l}\text { Open } \\
(n=43)\end{array}$ & $\begin{array}{l}\text { Conversion } \\
(n=11)\end{array}$ & $\mathrm{p}$ \\
\hline \multicolumn{5}{|l|}{ Resection type } \\
\hline Right hemicolectomy & $8(18.20 \%)$ & $10(23.30 \%)$ & $4(36.40 \%)$ & \multirow{5}{*}{$0.153 *$} \\
\hline Left hemicolectomy & $5(11.3 \%)$ & $3(7 \%)$ & $1(9.10 \%)$ & \\
\hline LAR & $30(68.20 \%)$ & $23(53.50 \%)$ & $4(36.40 \%)$ & \\
\hline APR & $1(2.30 \%)$ & $3(7 \%)$ & $2(18.20 \%)$ & \\
\hline Subtotal colectomy & 0 & $4(9.30 \%)$ & 0 & \\
\hline Operation duration (min.) & $180(90: 300)$ & $180(120: 420)$ & $180(120: 270)$ & $0.298 * *$ \\
\hline Morbidity & $9(20.50 \%)$ & $10(23.30 \%)$ & $7(63.60 \%)$ & $0.012^{*}$ \\
\hline Mortality & 0 & $2(4.70 \%)$ & $1(9.10 \%)$ & $0.098 *$ \\
\hline \multicolumn{5}{|c|}{$*$ Fisher-Freeman-Halton test, ${ }^{* *}$ Kruskal-Wallis test } \\
\hline \multicolumn{5}{|c|}{ Data were presented as median (minimum:maximum) or $\mathrm{n}(\%)$} \\
\hline \multicolumn{5}{|c|}{ LAR: Low anterior resection, APR: Abdominoperineal resection } \\
\hline
\end{tabular}




\section{Discussion}

Although laparoscopic resection for colorectal cancer is becoming more common, it is still used less frequently than open surgery. ${ }^{12}$ Apart from oncological factors, this is most likely because of the technical difficulties involved in laparoscopic techniques and the steep learning curve required. ${ }^{13}$ More surgical experience and anatomical awareness is required for oncologic resections performed on segments of the colon in different intra-abdominal locations,

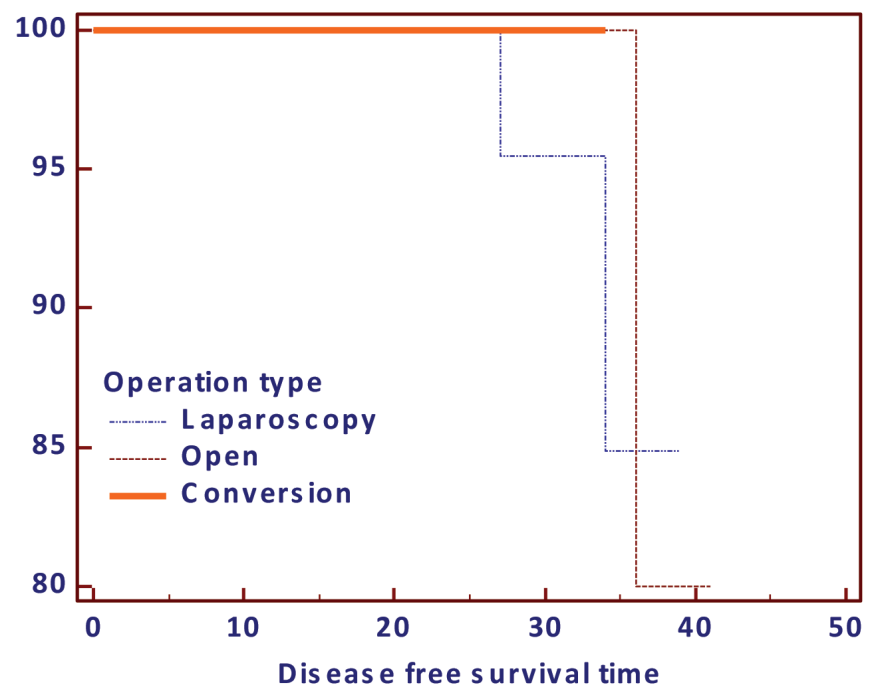

Figure 2. Disease free survival when compared to other laparoscopic interventions. With every laparoscopically completed surgery (colon mobilization, dissection and ligation of large veins, resection and anastomosis of the specimen), the surgeon's recognition of anatomic structures and surgical experience increases. ${ }^{14}$ As the procedures become more complex, conversion becomes a more significant complication. Although the level of surgical experience is often said to have no bearing on the decision to convert from laparoscopic to open surgery, some studies have noted that conversion is more likely to be adopted in the early stages of the learning curve. ${ }^{7}$ In our study, we observed that although conversion was performed in our early cases where our laparoscopic experience was inadequate; as our experience increased and better preoperative evaluations were made, conversion became unnecessary.

Laparoscopic resection rates in colorectal cancers vary between $27.7 \%$ and $51.1 \%$; in our study, laparoscopic resection was performed in $44.8 \%$ of the cases. ${ }^{15,16}$ Studies show that surgery time is significantly longer in laparoscopic resections (mean $216 \pm 53 \mathrm{~min}$ ) than in open surgery (mean $172 \pm 48 \mathrm{~min}$ ); while the exact length of time cannot be determined in conversion cases. ${ }^{17}$ Moreover, as the experience of the surgical team increases, operation time decreases. ${ }^{18}$ However, in our study, there was little difference in operation duration in the three groups. This could be due to the long surgery time and the limited number of patients in the three groups.

Table 3. Lymph node metastases, stages, recurrence and average follow-up time

\begin{tabular}{|c|c|c|c|c|}
\hline & $\begin{array}{l}\text { Laparoscopy } \\
(\mathrm{n}=44)\end{array}$ & $\begin{array}{l}\text { Open } \\
(n=43)\end{array}$ & $\begin{array}{l}\text { Conversion } \\
(n=11)\end{array}$ & $\mathrm{p}$ \\
\hline Removed lymph node & $17(8: 31)$ & $18(10: 95)$ & $17(11: 24)$ & $0.178^{*}$ \\
\hline Tumor size (mm) & $42.50(10: 150)$ & $50(10: 140)$ & $55(20: 100)$ & $0.626^{*}$ \\
\hline 2 & $12(27.30 \%)$ & $14(32.60 \%)$ & $1(9.10 \%)$ & \multirow{3}{*}{$0.701^{* *}$} \\
\hline 3 & $20(45.50 \%)$ & $16(37.20 \%)$ & $7(63.60 \%)$ & \\
\hline 4 & $3(6.80 \%)$ & $5(11.60 \%)$ & $1(9.10 \%)$ & \\
\hline 2 years survival (\%) & 95.70 & $100 \%$ & $100 \%$ & \\
\hline 3 years survival (\%) & $86.10 \%$ & $80 \%$ & $100 \%$ & \\
\hline
\end{tabular}


Reported conversion rates vary between $2 \%$ and $44 \%$ and the conversion rate in our study was $11.2 \%{ }^{7,19,20}$ Causes of conversion can be listed as patient-related factors (male gender, obesity, history of abdominal surgery, tumor size, neoadjuvant treatment); surgeon-related factors (surgical experience, technical facilities, patient volume); the surgical area to be resected (narrow pelvis particularly in male patients); intraoperative complications (organ injury, uncontrollable bleeding and anastomosis difficulties). ${ }^{16,21}$ In addition, in terms of resection type, rectum, proctectomy and left colon resections have higher rates of conversion. ${ }^{22}$ Patients with Crohn's disease and malignant cases have higher conversion rates than those with benign diseases (inflammatory diseases, diverticulitis). ${ }^{16,22}$ Advanced age is not a factor which increases the conversion rate but high conversion rates have been observed in obese patients $\left(\mathrm{BMI}>30 \mathrm{~kg} / \mathrm{m}^{2}\right){ }^{23,24}$ A history of abdominal surgery is not considered as a contraindication for surgical laparoscopic interventions, although it is a relative contraindication. While a history of abdominal and pelvic surgery increases the risk of conversion, a history of appendectomy and cholecystectomy are not reported to increase the risk of conversion. ${ }^{9}$ However, in our study, conversion was necessary in $18.1 \%$ patients with a history of appendectomy due to severe cohesive adhesion. Relatively high conversion rates in our cases were assumed to be due to the inexperience of one surgeon. The most frequent causes of conversion were intraabdominal severe cohesive adhesion and invasion of the tumor into the surrounding tissue.

When the outcomes of patients undergoing laparoscopy or conversion surgery are compared, a higher rate of morbidity is seen in both groups compared to those having open surgery, according to the literature. ${ }^{25}$ While no difference in terms of morbidity and mortality are reported between conversion patients and the open surgery group in this report, another study reports a higher complication rate and a longer period of hospitalization in conversion patients compared to those having laparoscopy or open surgery. ${ }^{8,26}$ The morbidity rate is reported as $23 \%$ after laparoscopy, $11-20 \%$ after open surgery, and $35.2 \%$ after conversion. ${ }^{16,27,28,29}$ Although the incidence of wound site infection and incisional hernia decreases following laparoscopic resections; postoperative ileus, anastomosis leakage, wound site infection and duration of hospitalization increase in patients undergoing conversion. ${ }^{16}$

In our study, morbidity was also most frequently observed in the conversion group. The incidence of wound site infection, is reported as the most frequent cause of morbidity: 10-12\% in open surgery cases and $32.1 \%$ in conversion patients. ${ }^{30} \mathrm{In}$ our study, the most frequent cause of morbidity in all three groups was wound site infection; and in morbidity subgroup analysis, the morbidity incidence was found to be higher in the conversion group than in either the laparoscopy or open surgery groups. Likewise, reported incidences of anastomosis leakage are 2.4-6.8\% after open surgery, $2.7 \%$ after laparoscopy, but $25 \%$ after conversion. ${ }^{25,31}$ However, in our study, anastomosis leakage was observed in laparoscopy and open surgery groups but not in the conversion group. In conversion patients, the incidence of mortality is reported to be $3.5 \% .^{32}$ In our cases, mortality was observed in $9.09 \%$ of the conversion group.

In colorectal cancer cases, lymph nodes have a prognostic value in determining the stage. Studies report that as surgeons gain more experience, the number of lymph nodes removed increases and that at least 12 lymph nodes should be removed for a sufficient lymph node dissection. ${ }^{33}$ Analysis of resected pieces has shown that 14-19 lymph nodes are removed in laparoscopic resections whereas 15-23 lymph nodes are removed in open surgical resections. ${ }^{15,34}$ In our study, the number of removed lymph nodes was similar in all groups and no statistically significant differences were found between the resection methods.

The average tumor size in colorectal cancers is $3.5(1-7) \mathrm{cm}$ in the laparoscopic group and 3.9 (1-8) in the open surgery group. ${ }^{34}$ In our study, although average tumor size was larger in the conversion group, no statistically significant difference was found among the groups.

When stages are analyzed in patients with colorectal cancer, stage 3 is reported as the most common stage in both laparoscopy and open surgery groups (34.2\%, 37.7\%, respectively). ${ }^{15}$ In our study, our cases were also most frequently stage 3 . Although stage 3 was relatively more frequently observed in the conversion group, no statistically significant difference was found among the groups.

Three and five-year survival rates are also similar in laparoscopy and open surgery groups. ${ }^{6,35}$ When overall survival is evaluated over a 10 -year period, it is $45.3 \%$ in laparoscopic resections and $40.9 \%$ in open surgical resections. ${ }^{15}$ Disease-free survival rate is $64.9 \%$ in laparoscopic resections and $59.8 \%$ in open surgical resections. ${ }^{15}$ In our study, one, two, and three-year survival rates revealed no statistical differences between the resection methods.

Nonetheless, there are some limitations in the interpretation of the data in our study. First of all, the number of patients included in our study and in the resection type subgroups is relatively small. Also, although groups were assigned according to the resection method used, there were biological differences between colon and rectal cancers. Linking high rates of conversion to open laparoscopy to 
surgical inexperience is only an assumption. Finally, the inability to perform randomization among the groups, and the retrospective nature of the study are also limitations. In conclusion, in patients with colorectal cancer, laparoscopic resections can be performed safely and effectively, with similar results to open surgery. To overcome the technical difficulties and understand the two-dimensional anatomical structures of laparoscopy, a learning curve is required. However, we have limited data on the conversion outcomes following minimal invasive surgery. Therefore, there is no consensus of opinion on whether to recommend laparoscopic interventions to every patient with colorectal pathology, or how to identify patients with a higher risk of conversion. Despite the indisputable success of laparoscopic surgery, we believe that selection of appropriate patients and clarification of the reasons for conversion are of utmost importance in giving the best results after laparoscopic colectomy.

\section{Ethics}

Ethics Committee Approval: Retrospective study.

Informed Consent: Consent form was filled out by all participants.

Peer-review: External and internal peer-reviewed.

\section{Authorship Contributions}

Surgical and Medical Practices: U.E.E., H.M.Ç., Concept: U.E.E., Design: H.M.Ç., Data Collection or Processing: U.E.E., H.M.Ç., Analysis or Interpretation: U.E.E., H.M.Ç., Literature Search: H.M.Ç., Writing: U.E.E.

Conflict of Interest: No conflict of interest was declared by the authors.

Financial Disclosure: The authors declared that this study received no financial support.

\section{References}

1. Phillips EH, Franklin M, Carroll BJ, Fallas MJ, Ramos R, Rosenthal D. Laparoscopic colectomy. Ann Surg 1992;216: 703-707.

2. Kwon S, Billingham R, Farrokhi E, Florence M, Herzig D, Horvath K, Rogers T, Steele S, Symons R, Thirlby R, Whiteford M, Flum DR. Adoption of laparoscopy for elective colorectal resection: a report from the Surgical Care and Outcomes Assessment Program. J Am Coll Surg 2012;214: 909918

3. Green BL, Marshall HC, Collinson F, Quirke P, Guillou P, Jayne DG, Brown JM. Long-term follow-up of the Medical Research Council CLASICC trial of conventional versus laparoscopically assisted resection in colorectal cancer Br J Surg 2013;100:75-82.

4. Rea JD, Cone MM, Diggs BS, Deveney KE, Lu KC, Herzig DO. Utilization of laparoscopic colectomy in the United States before and after the clinical outcomes of surgical therapy study group trial. Ann Surg 2011;254:281-8

5. McKay GD, Morgan MJ, Wong SK, Gatenby AH, Fulham SB, Ahmed KW, Toh JW, Hanna M, Hitos K; South Western Sydney Colorectal Tumor Group. Improved short-term outcomes of laparoscopic versus open resection for colon and rectal cancer in an area health service: a multicenter study. Dis Colon Rectum 2012;55:42-50
6. Fleshman J, Sargent DJ, Green E, Anvari M, Stryker SJ, Beart RW Jr, Hellinger M, Flanagan R Jr, Peters W, Nelson H; Clinical Outcomes of Surgical Therapy Study Group. Laparoscopic colectomy for cancer is not inferior to open surgery based on 5- year data from the COST Study Group trial. Ann Surg 2007;246:655-62.

7. Gervaz P, Pikarsky A, Utech M, Secic M, Efron J, Belin B, Jain A, Wexner SD. Converted laparoscopic colorectal surgery. Surg Endosc 2001;15: 827-832.

8. Casillas S, Delaney CP, Senagore AJ, Brady K, Fazio VW. Does conversion of a laparoscopic colectomy adversely affect patient outcome? Dis Colon Rectum 2004:47:1680-1685.

9. Franko J, Fassler SA, Rezvani M, O'Connell BG, Harper SG, Nejman JH, Zebley DM. Conversion of laparoscopic colon resection does not affect survival in colon cancer. Surg Endosc 2008;22:2631-2634

10. Chan AC, Poon JT, Fan JK, Lo SH, Law WL. Impact of conversion on the long-term outcome in laparoscopic resection of colorectal cancer. Surg Endosc 2008;22:2625-2630.

11. Milsom JW, Bohm B. Laparoscopic Colorectal Surgery. Springer: New York, 1996.

12. Ivatury SJ, Bostock Rosenzweig IC, Holubar SD. Short-term Outcomes After Open and Laparoscopic Colostomy Creation. Dis Colon Rectum 2016:59:543-550

13. Swanstrom LL, Soper NJ. Mastery of Endoscopic and Laparoscopic Surgery. Lippincott Williams \& Wilkins, Philadelphia, Pa, USA, 4th edition, 2014.

14. Nguyen NT, Scott-Conner CEH. The SAGES Manual, Springer, New York, NY, USA, 3rd edition, 2012

15. Pecorelli N, Amodeo S, Frasson M, Vignali A, Zuliani W, Braga M. Tenyear outcomes following laparoscopic colorectal resection: results of a randomized controlled trial. Int J Colorectal Dis 2016;31:1283-90.

16. Masoomi H, Moghadamyeghaneh Z, Mills S, Carmichael JC, Pigazzi A, Stamos MJ. Risk Factors for Conversion of Laparoscopic Colorectal Surgery to Open Surgery: Does Conversion Worsen Outcome?. World J Surg 2015;39:1240-7.

17. Lourenco T, Murray A, Grant A, McKinley A, Krukowski Z, Vale L. Laparoscopic surgery for colorectal cancer: safe and effective?-A systematic review. Surg Endosc 2008;22:1146-60.

18. Li JC, Lo AW, Hon SS, Ng SS, Lee JF, Leung KL. Institution learning curve of laparoscopic colectomy-a multi-dimensional analysis. Int J Colorectal Dis 2012;27:527-33.

19. Vaccaro CA, Rossi GL, Quintana GO, Soriano ER, Vaccarezza H, Rubinstein F. Laparoscopic colorectal resections: a simple predictormodel and a stratification risk for conversion to open surgery. Dis Colon Rectum 2014:57:869-74.

20. Cima RR, Hassan I, Poola VP, Larson DW, Dozois EJ, Larson DR, O'Byrne MM, Huebner M. Failure of institutionally derived predictive models of conversion in laparoscopic colorectal surgery to predict conversion outcomes in an independent data set of 998 laparoscopic colorectal procedures. Ann Surg 2010;251:652-8.

21. Kuhry E, Bonjer HJ, Haglind E, Hop WC, Veldkamp R, Cuesta MA, Jeekel J, Påhlman L, Morino M, Lacy A, Delgado S; COLOR Study Group. Impact of hospital case volume on short-term outcome after laparoscopic operation for colonic cancer. Surg Endosc 2005;19:687-92.

22. Tan PY, Stephens JH, Rieger NA, Hewett PJ. Laparoscopically assisted colectomy: a study of risk factors and predictors of open conversion. Surg Endosc 2008;22:1708-1714.

23. Cayci HM, Erdogdu UE, Turkoglu MA, Orman S, Cantay H, Dilektasli E. Colorectal surgery in octogenarian patients: is it safe?. Eur Res J 2017;3(2):111-117.

24. Pikarsky AJ, Saida Y, Yamaguchi T, Martinez S, Chen W, Weiss EG Nogueras JJ, Wexner SD. Is obesity a high risk factor for laparoscopic colorectal surgery? Surg Endosc 2002;16:855-858 
25. Slim K, Pezet D, Riff Y, Clark E, Chipponi J. High morbidity rate after converted laparoscopic colorectal surgery. Br J Surg 1995;82: 1406-1408.

26. Kang CY, Chaudhry OO, Halabi WJ, Nguyen V, Carmichael JC, Stamos MJ, Mills S. Outcomes of laparoscopic colorectal surgery: data from the Nationwide Inpatient Sample 2009. Am J Surg 2012;204:952-7.

27. Clinical Outcomes of Surgical Therapy Study Group (COST). A comparison of laparoscopically assisted and open colectomy for colon cancer. N Engl J Med 2004;350:2050-9.

28. Veldkamp R, Kuhry E, Hop WC, Jeekel J, Kazemier G, Bonjer HJ, Haglind E, Påhlman L, Cuesta MA, Msika S, Morino M, Lacy AM; COlon cancerLaparoscopic or Open Resection Study Group (COLOR). Laparoscopic surgery versus open surgery for colon cancer: short-term outcomes of a randomised trial. Lancet Oncol 2005;6:477-84.

29. Guillou PJ, Quirke P, Thorpe H, Walker J, Jayne DG, Smith AM, Heath RM, Brown JM; MRC CLASICC trial group. Short-term endpoints of conventional versus laparoscopic-assisted surgery in patients with colorectal cancer (MRC CLASICC trial): multicentre, randomised controlled trial. Lancet 2005;365:1718-26.

30. Smith EL, Bohl JK, McElearney ST, Friel CM, Barclay MM, Sawyer RG, Foley EF. Wound infection after elective colorectal resection. Ann Surg 2004;239:599-605.
31. Reinke CE, Showalter S, Mahmoud NN, Kelz RR. Comparison of anastomotic leak rate after colorectal surgery using different databases. Dis Colon Rectum 2013;56:638-44.

32. Marusch F, Gastinger I, Schneider C, Scheidbach H, Konradt J, Bruch HP, Köhler L, Bärlehner E, Köckerling F; Laparoscopic Colorectal Surgery Study Group (LCSSG). Importance of conversion for results obtained with laparoscopic colorectal surgery. Dis Colon Rectum 2001;44:207-14.

33. Prakash K, Kamalesh NP, Pramil K, Vipin IS, Sylesh A, Jacob M. Does case selection and outcome following laparoscopic colorectal resection change after initial learning curve?Analysis of 235 consecutive elective laparoscopic colorectal resections. J Minim Access Surg 2013 9:99-103.

34. Neudecker J, Klein F, Bittner R, Carus T, Stroux A, Schwenk W; LAPKON II Trialists. Short-term outcomes from a prospective randomized trial comparing laparoscopic and open surgery for colorectal cancer. Br J Surg 2009;96:1458-67.

35. Jayne DG, Thorpe HC, Copeland J, Quirke P, Brown JM, Guillou PJ. Five-year follow-up of the Medical Research Council CLASICC trial of laparoscopically assisted versus open surgery for colorectal cancer. $\mathrm{Br} \mathrm{J}$ Surg 2010;97:1638-45. 